\title{
A Summary of Crew Workload and Situational Awareness Ratings for U.S. Army Aviation Aircraft
}

\author{
by Jamison S. Hicks, David B. Durbin, Anthony W. Morris, and
}

Brad M. Davis 


\section{NOTICES}

\section{Disclaimers}

The findings in this report are not to be construed as an official Department of the Army position unless so designated by other authorized documents.

Citation of manufacturer's or trade names does not constitute an official endorsement or approval of the use thereof.

Destroy this report when it is no longer needed. Do not return it to the originator. 


\section{Army Research Laboratory}

Aberdeen Proving Ground, MD 21005-5425

ARL-TR-6955

June 2014

\section{A Summary of Crew Workload and Situational Awareness Ratings for U. S. Army Aviation Aircraft}

Jamison S. Hicks, David B. Durbin, Anthony W. Morris, and Brad M. Davis Human Research and Engineering Directorate, ARL 


\section{REPORT DOCUMENTATION PAGE}

Public reporting burden for this collection of information is estimated to average 1 hour per response, including the time for reviewing instructions, searching existing data sources, gathering and maintaining the data needed, and completing and reviewing the collection information. Send comments regarding this burden estimate or any other aspect of this collection of information, including suggestions for reducing the burden, to Department of Defense, Washington Headquarters Services, Directorate for Information Operations and Reports (0704-0188), 1215 Jefferson Davis Highway, Suite 1204, Arlington, VA 22202-4302. Respondents should be aware that notwithstanding any other provision of law, no person shall be subject to any penalty for failing to comply with a collection of information if it does not display a currently valid OMB control number.

PLEASE DO NOT RETURN YOUR FORM TO THE ABOVE ADDRESS.

\begin{tabular}{l|l}
\hline $\begin{array}{l}\text { 1. REPORT DATE }(D D-M M-Y Y Y Y) \\
\text { June } 2014\end{array}$ & $\begin{array}{l}\text { 2. REPORT TYPE } \\
\text { Final }\end{array}$ \\
\hline $\begin{array}{l}\text { 4. TITLE AND SUBTITLE } \\
\text { A Summary of Crew Workload and Situational Awareness Ratings for U.S. Army } \\
\text { Aviation Aircraft }\end{array}$
\end{tabular}

Aviation Aircraft

3. DATES COVERED (From - To)

September-December 2013

5a. CONTRACT NUMBER

5b. GRANT NUMBER

5c. PROGRAM ELEMENT NUMBER

6. AUTHOR(S)

Jamison S. Hicks, David B. Durbin, Anthony W. Morris, and Brad M. Davis

5d. PROJECT NUMBER

62716АH70

5e. TASK NUMBER

5f. WORK UNIT NUMBER

7. PERFORMING ORGANIZATION NAME(S) AND ADDRESS(ES)

8. PERFORMING ORGANIZATION REPORT NUMBER

U.S. Army Research Laboratory

ATTN: RDRL-HRM-DJ

Aberdeen Proving Ground, MD 21005-5425

9. SPONSORING/MONITORING AGENCY NAME(S) AND ADDRESS(ES)

ARL-TR-6955

10. SPONSOR/MONITOR'S ACRONYM(S)

11. SPONSOR/MONITOR'S REPORT

NUMBER(S)

\section{DISTRIBUTION/AVAILABILITY STATEMENT}

Approved for public release; distribution is unlimited.

\section{SUPPLEMENTARY NOTES}

\section{ABSTRACT}

The U.S. Army Research Laboratory Human Research and Engineering Directorate (ARL/HRED) assesses crewstation design for new and upgraded U.S. Army Aviation aircraft during simulations and operational testing. The assessments are conducted to identify and eliminate human factors design problems. ARL/HRED evaluates pilot workload and situational awareness (SA) during simulations and operational testing to assess crewstation design. To date, more than 12,000 pilot workload ratings and 3000 pilot SA ratings have been collected by ARL/HRED for Army aircraft. This report summarizes the Bedford Workload Rating Scale, Situation Awareness Rating Technique, and China Lake Situational Awareness scale ratings collected during simulations and operational testing to assess crewstation design.

\section{SUBJECT TERMS}

workload, situation awareness, Apache Longbow, UH60M, CH47H, simulation, U.S. Army Aviation

16. SECURITY CLASSIFICATION OF:

\begin{tabular}{|l|l|l|}
\hline a. REPORT & b. ABSTRACT & c. THIS PAGE \\
Unclassified & Unclassified & Unclassified \\
\hline
\end{tabular}

\begin{tabular}{l|l}
$\begin{array}{l}\text { 17. LIMITATION } \\
\text { OF ABSTRACT }\end{array}$ & \\
UU &
\end{tabular}

NUMBER OF PAGES

50 19a. NAME OF RESPONSIBLE PERSON Jamison Hicks

19b. TELEPHONE NUMBER (Include area code) $334-255-2203$ 


\section{Contents}

List of Figures $\quad$ v

List of Tables $\quad$ v

1. Assessment of Crew Workload and Situational Awareness 1

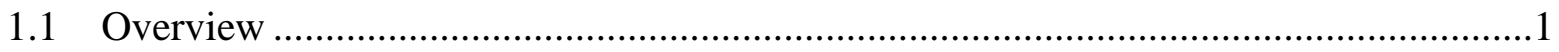

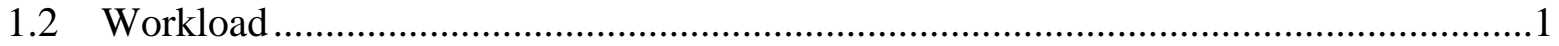

1.2.1 Bedford Workload Rating Scale......................................................................2

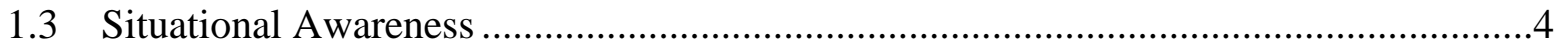

1.4 Situation Awareness Rating Technique and China Lake Situational Awareness Scale..5

1.5 Situation Awareness of Battlefield Elements ...............................................................

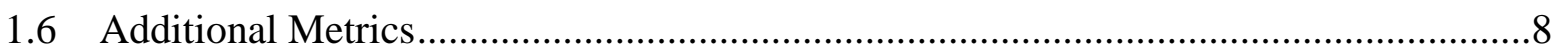

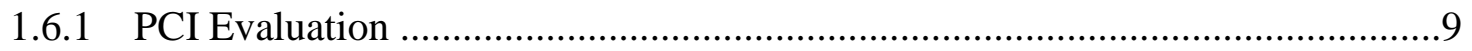

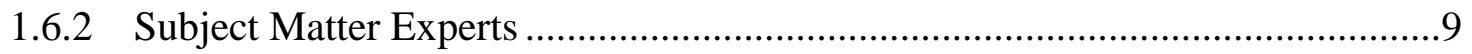

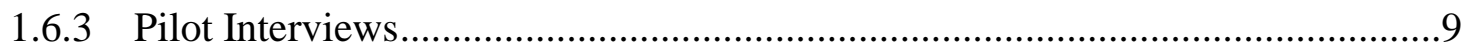

2. Crewstation Assessment During Simulation and Operational Testing 9

2.1 Crewstation Assessment Methodology .......................................................................

2.2 Simulation and Operational Testing ......................................................................10

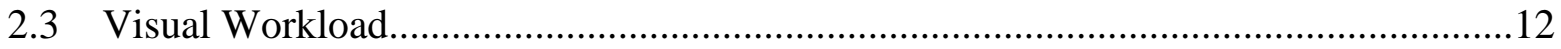

3. Workload and SA Ratings $\quad 13$

3.1 Bedford Workload Rating Scale Ratings ..............................................................13

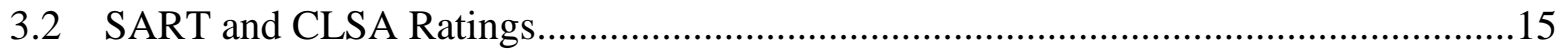

$\begin{array}{lll}\text { 4. Summary } & 16\end{array}$

$\begin{array}{llr}\text { 5. } & \text { References } & 18\end{array}$

Appendix A. Bedford Workload Rating Scale and Questionnaire 19

Appendix B. SART and CLSA Rating Scales 23 
Appendix C. PCI Questionnaire Example

Appendix D. SME Questionnaire

List of Symbols, Abbreviations, and Acronyms

Distribution List 


\section{List of Figures}

Figure 1. Bedford Workload Rating Scale ..........................................................................

Figure 2. Endsley model of situation awareness in dynamic decisionmaking. ...........................5

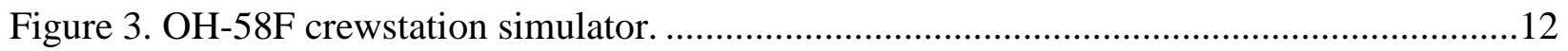

Figure 4. AH-64D Apache Longbow crewstation simulator..................................................12

Figure 5. Eye tracker data collected from AH-64D Apache ...................................................13

\section{List of Tables}

Table 1. Sample flight and mission task list. ...................................................................4

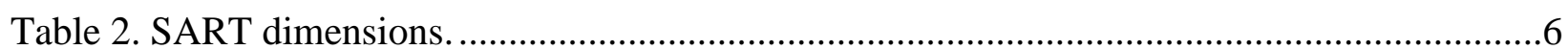

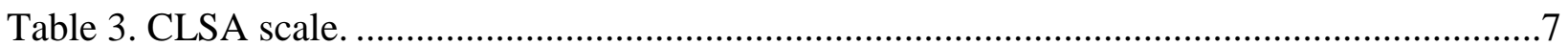

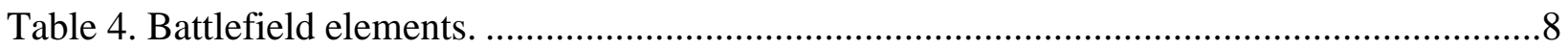

Table 5. U.S. Army aircraft, associated simulator, and assessment or test. ..............................11

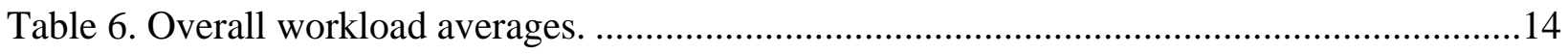

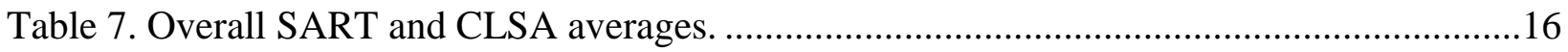


INTENTIONALLY LEFT BLANK. 


\section{Assessment of Crew Workload and Situational Awareness}

\subsection{Overview}

Effective aircrew performance is critical to mission success. Crewstations that are designed to augment the cognitive and physical abilities of aircrews help minimize pilot workload, enhance situational awareness (SA), and contribute to successful mission performance. It is vital that crewstations be assessed early and often during development to ensure optimal design.

The U.S. Army Research Laboratory's Human Research and Engineering Directorate (ARL/HRED) assesses crewstation design for new and upgraded Army Aviation aircraft during simulations and operational testing. The assessments are conducted to identify and eliminate human factors design problems. ARL/HRED evaluates pilot workload and SA during simulations and operational testing to assess crewstation design. To date, more than 12,000 pilot workload ratings and 3000 pilot SA ratings have been collected by ARL/HRED for Army aircraft. This report summarizes the Bedford Workload Rating Scale (BWRS), Situation Awareness Rating Technique (SART), and China Lake Situational Awareness (CLSA) scale ratings collected during simulations and operational testing to assess crewstation design.

\subsection{Workload}

There are several definitions of pilot workload. A useful definition is "the integrated mental and physical effort required to satisfy the perceived demands of a specified flight task" (Roscoe, 1985). It is important to assess pilot workload because mission accomplishment is related to the mental and physical ability of the crew to effectively perform their flight and mission tasks. If one or both pilots experience excessively high workload while performing flight and mission tasks, the tasks may be performed ineffectively or abandoned. In general, workload assessment techniques are used to answer the following questions (Eisen, 1987):

- Does the operator have the capability to perform the required tasks?

- Does the operator have enough spare capacity to take on additional tasks?

- Does the operator have enough spare capacity to cope with emergency situations?

- Can the task or equipment be altered to increase the amount of spare capacity?

- Can the task or equipment be altered to increase/decrease the amount of mental workload?

- How does the workload of a new system compare with the old system?

To assess whether the pilots are task-overloaded during the missions, the level of workload for each pilot must be evaluated. 


\subsubsection{Bedford Workload Rating Scale}

The BWRS has been used extensively by the military, civil, and commercial aviation communities for pilot workload estimation (Roscoe and Ellis, 1990). It requires pilots to rate the level of workload associated with a task based on the amount of spare capacity they feel they have to perform additional tasks. Spare workload capacity is an important commodity for pilots because they are often required to perform several tasks concurrently. For example, pilots often perform navigation tasks, communicate via multiple radios, monitor aircraft systems, and assist the pilot on the controls with flight tasks (e.g., maintain airspace surveillance) within the same time interval. Mission performance is reduced if pilots are task-saturated and have little or no spare capacity to perform other tasks.

After each mission, pilots rate flight and mission tasks using the BWRS scale (figure 1). Roscoe and Ellis (1990) describe the BWRS and explain its use in assessing pilot workload. The pilot starts the decisionmaking process at the bottom left corner of the decision tree, which consists of three questions requiring yes or no answers, in order to proceed to the descriptions of different levels of workload. The descriptors denote increasing levels of workload associated with ratings 1-10. The flight and mission tasks should be well defined and the workload being assessed should be related to the execution of the primary task; any additional tasks (e.g., monitoring communications) must be included as part of spare capacity. Once the pilot settles on a workload rating using the decision tree, the rating is made for the task for the mission or mission segment. A sample task list used by ARL/HRED is shown in table 1 and a full task list is in appendix A. For several aircraft, ARL/HRED wrote the workload requirement that operation of the aircraft must not result in aggregate pilot BWRS task and mission ratings of more than 5.0-6.0. Flight and mission tasks that are rated 5.0 or above are evaluated to determine if crewstation design problems contributed to higher workload ratings. 


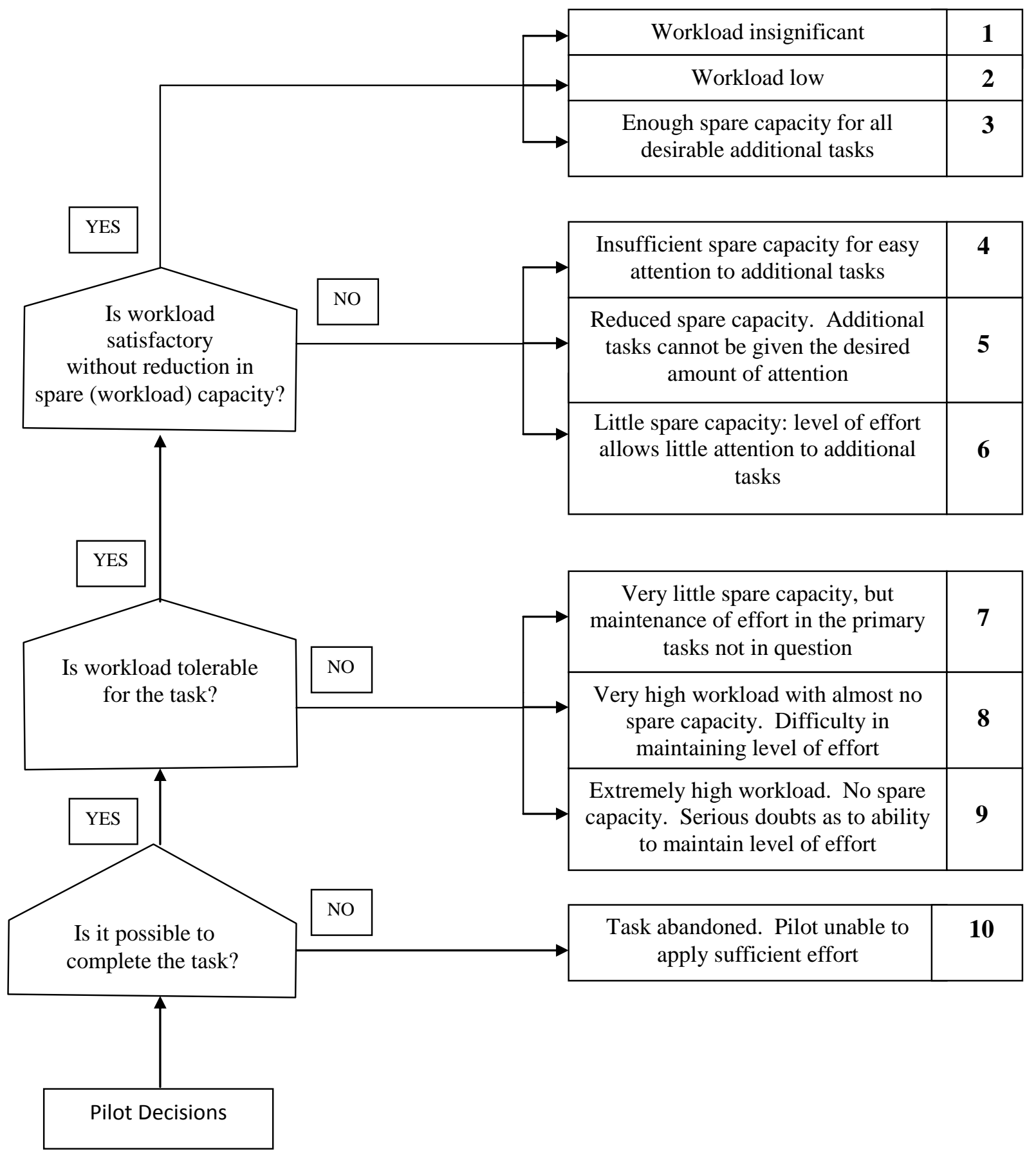

Figure 1. Bedford Workload Rating Scale. 
Table 1. Sample flight and mission task list.

\begin{tabular}{|c|c|c|}
\hline $\begin{array}{c}\text { Task } \\
\text { No. }\end{array}$ & Flight and Mission Tasks & Workload Rating \\
\hline 1026 & Maintain airspace surveillance & \\
\hline 1028 & Perform hover power check & \\
\hline 1030 & Perform hover out-of-ground-effect check & \\
\hline 1032 & Perform radio communication procedures & \\
\hline 1038 & Perform hovering flight & \\
\hline
\end{tabular}

\subsection{Situational Awareness}

SA can be defined as the pilot's mental model of the current state of the flight and mission environment. A more formal definition is "The perception of the elements in the environment within a volume of time and space, the comprehension of their meaning, and the projection of their status in the near future" (Endsley, 1988). The Endsley model of SA in dynamic decisionmaking can be seen in figure 2 (Endsley, 1995). The SA model encompasses three levels of SA. Level 1 includes the perception of elements in the current situation, level 2 is the comprehension of the current situation, and level 3 is the projection of future status. The understanding of how these three levels of SA form an overview of pilot understanding is important. Each mission segment and stimulus may call for different levels of SA. Maintaining a single level of SA would not be appropriate for all scenarios, especially when evaluated with workload. For example, a requirement for level $3 \mathrm{SA}$ in all scenarios would burden pilots with workload requirements to maintain and identify level $3 \mathrm{SA}$ for all variables. Ideally, SA is transferred at different levels among relative variable occurrences, and an overall concept of the mission and aircraft parameters is established that is constantly revised throughout the mission and based on pilot actions. It is important to assess SA because of its potential to directly impact pilot and aircraft performance. Good SA should increase the probability of good decisionmaking and performance by aircrews when conducting flight and mission tasks. 


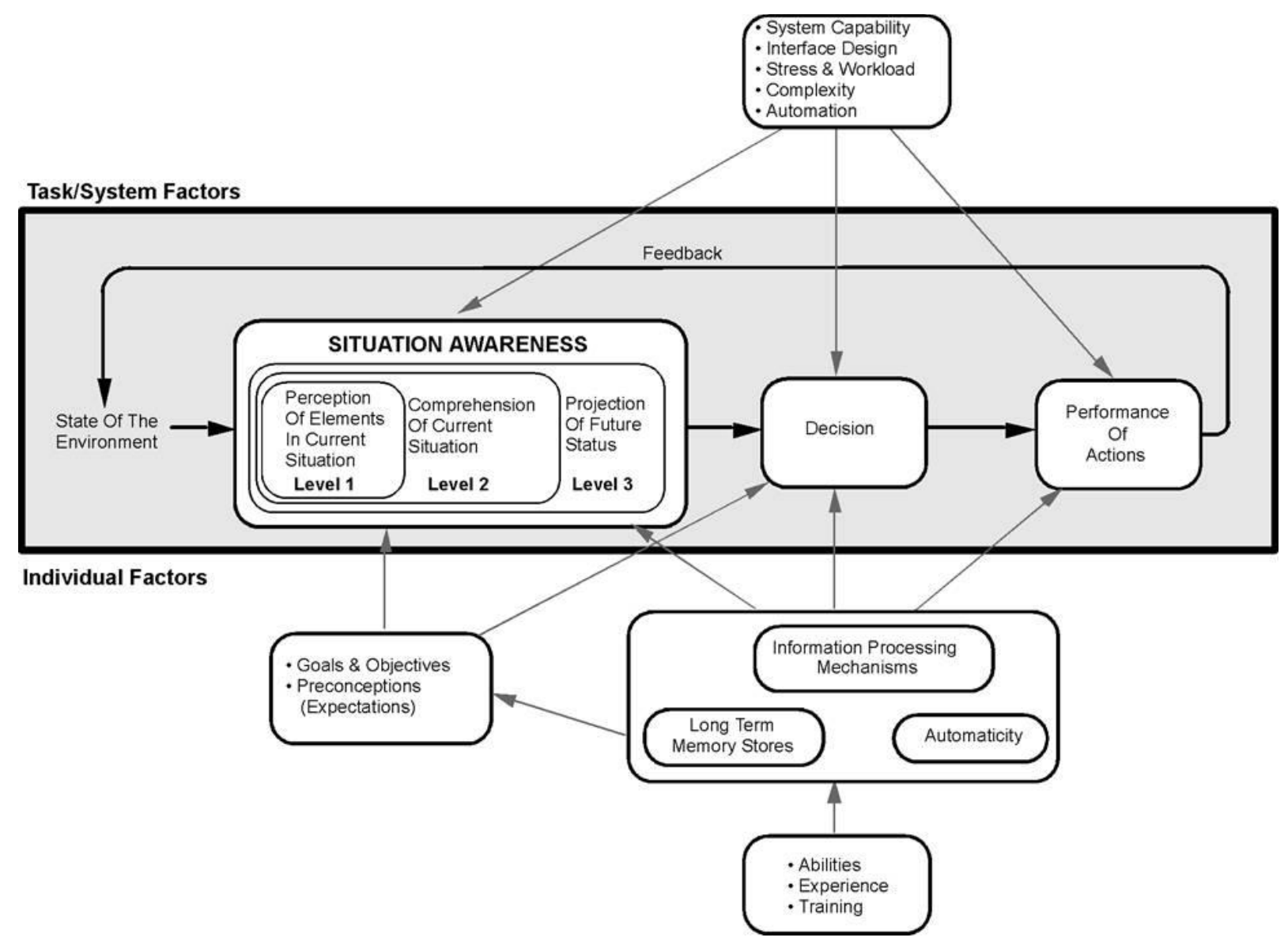

Figure 2. Endsley model of situation awareness in dynamic decisionmaking.

\subsection{Situation Awareness Rating Technique and China Lake Situational Awareness Scale}

The SART (appendix B) is a multidimensional rating scale for pilots to report their perceived SA. SART uses 10 dimensions (table 2) to measure operator SA: familiarity of the situation, focusing of attention, information quantity, information quality, instability of the situation, concentration of attention, complexity of the situation, variability of the situation, arousal, and spare mental capacity. SART is administered after each mission by ARL/HRED personnel and involves the participant rating each dimension on a seven-point rating scale $(1=$ low, $7=$ high $)$ to gain a subjective measure of SA (Salmon et al., 2006). SART was developed as an evaluation tool for the design of aircrew systems (Taylor, 1989) and assesses three components of SA: understanding, supply, and demand. These components are subcategories that contain the 10 dimensions. Taylor proposed that SA depends on the pilot's understanding (U) (e.g., quality of information they receive) and the difference between the demand (D) on the pilot's resources (e.g., complexity of mission) and the pilot's supply (S) (e.g., ability to concentrate). When D exceeds $S$, there is a negative effect on $U$ and an overall reduction of $S A$. The formula $\mathrm{SA}=\mathrm{U}-(\mathrm{D}-\mathrm{S})$ is used to derive the overall SART score. The SART is one of the most thoroughly tested rating scales for estimating SA (Endsley, 2000). 
Table 2. SART dimensions.

\begin{tabular}{|c|c|}
\hline \multicolumn{2}{|r|}{ Situation Awareness Rating Technique (SART) } \\
\hline \multicolumn{2}{|r|}{ Demand } \\
\hline $\begin{array}{c}\text { Instability of } \\
\text { situation }\end{array}$ & Likeliness of situation to change suddenly \\
\hline $\begin{array}{l}\text { Variability of } \\
\text { situation }\end{array}$ & Number of variables that require your attention \\
\hline $\begin{array}{l}\text { Complexity of } \\
\text { situation }\end{array}$ & Degree of complication (number of closely connected parts) of the situation \\
\hline \multicolumn{2}{|r|}{ Supply } \\
\hline Arousal & $\begin{array}{l}\text { Degree to which you are ready for activity; ability to anticipate and keep up with the flow of } \\
\text { events }\end{array}$ \\
\hline $\begin{array}{l}\text { Spare mental } \\
\text { capacity }\end{array}$ & Amount of mental ability available to apply to new tasks \\
\hline Concentration & $\begin{array}{l}\text { Degree to which your thoughts are brought to bear on the situation; degree to which you } \\
\text { focused on important elements and events }\end{array}$ \\
\hline $\begin{array}{l}\text { Division of } \\
\text { attention }\end{array}$ & $\begin{array}{l}\text { Ability to divide your attention among several key issues during the mission; ability to } \\
\text { concern yourself with many aspects of current and future events simultaneously }\end{array}$ \\
\hline \multicolumn{2}{|r|}{ Understanding } \\
\hline $\begin{array}{c}\text { Information } \\
\text { quantity }\end{array}$ & Amount of knowledge received and understood \\
\hline $\begin{array}{l}\text { Information } \\
\text { quality }\end{array}$ & Degree of goodness or value of knowledge communicated \\
\hline Familiarity & Degree of acquaintance with the situation \\
\hline
\end{tabular}

ARL/HRED personnel also use the CLSA (table 3), which is a five-point SA scale that pilots use to rate their perceived level of SA for the mission or mission segment. The scale relates to general knowledge of aircraft systems, the tactical environment, and the mission objectives as well as the ability to accommodate trends and the level of task shedding due to high workload. The CLSA is considered to have positive attributes of high face validity or "common sense," clear criteria, ease of use, and ease of analysis. 
Table 3. CLSA scale.

\begin{tabular}{|c|l|}
\hline CLSA Scale Value & \multicolumn{1}{|c|}{ Content } \\
\hline Very good -1 & $\begin{array}{l}\text { Full knowledge of aircraft energy state, and tactical environment/mission } \\
\text { Full ability to anticipate/accommodate trends }\end{array}$ \\
\hline Good -2 & $\begin{array}{l}\text { Full knowledge of aircraft energy state, tactical environment and mission } \\
\text { Partial ability to anticipate/accommodate trends } \\
\text { No task shedding }\end{array}$ \\
\hline Adequate -3 & $\begin{array}{l}\text { Full knowledge of aircraft energy state, tactical environment and mission } \\
\text { Saturated ability to anticipate and accommodate trends } \\
\text { Some shedding of minor tasks }\end{array}$ \\
\hline Poor -4 & $\begin{array}{l}\text { Fair knowledge of aircraft energy state, tactical environment, and mission } \\
\text { Saturated ability to anticipate and accommodate trends } \\
\text { Shedding of all minor tasks as well as many not essential to flight safety/mission } \\
\text { effectiveness }\end{array}$ \\
\hline Very poor -5 & $\begin{array}{l}\text { Minimal knowledge of aircraft energy state, tactical environment, and mission } \\
\text { Oversaturated ability to anticipate and accommodate trends } \\
\text { Shedding of all tasks not essential to flight safety and mission effectiveness }\end{array}$ \\
\hline
\end{tabular}

\subsection{Situation Awareness of Battlefield Elements}

Assessing crew SA of battlefield elements (table 4) is important to evaluate their comprehension of the elements (e.g., threat vehicles) during simulation and testing. Pilots provide ratings for each element, and these ratings are used to determine whether the elements are identified and understood throughout the mission. 
Table 4. Battlefield elements.

\begin{tabular}{|c|c|c|c|c|c|}
\hline $\begin{array}{l}\text { Battlefield } \\
\text { Elements }\end{array}$ & $\begin{array}{c}\text { Very High } \\
\text { Level of } \\
\text { Situation } \\
\text { Awareness } \\
\end{array}$ & $\begin{array}{c}\text { Fairly High } \\
\text { Level of } \\
\text { Situation } \\
\text { Awareness } \\
\end{array}$ & Borderline & $\begin{array}{c}\text { Fairly Low } \\
\text { Level of } \\
\text { Situation } \\
\text { Awareness } \\
\end{array}$ & $\begin{array}{c}\text { Very Low } \\
\text { Level of } \\
\text { Situation } \\
\text { Awareness } \\
\end{array}$ \\
\hline \multicolumn{6}{|l|}{$\begin{array}{l}\text { Location of } \\
\text { enemy units }\end{array}$} \\
\hline \multicolumn{6}{|l|}{$\begin{array}{l}\text { Location of } \\
\text { friendly units }\end{array}$} \\
\hline \multicolumn{6}{|l|}{$\begin{array}{l}\text { Location of } \\
\text { noncombatants } \\
\text { (e.g., civilians) }\end{array}$} \\
\hline \multicolumn{6}{|l|}{$\begin{array}{l}\text { Location of my } \\
\text { aircraft during } \\
\text { missions }\end{array}$} \\
\hline \multicolumn{6}{|l|}{$\begin{array}{l}\text { Location of } \\
\text { other aircraft } \\
\text { in my flight }\end{array}$} \\
\hline \multicolumn{6}{|l|}{$\begin{array}{l}\text { Location of } \\
\text { cultural } \\
\text { features (e.g., } \\
\text { bridges) }\end{array}$} \\
\hline \multicolumn{6}{|l|}{$\begin{array}{c}\text { Route } \\
\text { information } \\
\text { (e.g., air } \\
\text { control points) }\end{array}$} \\
\hline $\begin{array}{l}\text { Status of my } \\
\text { aircraft } \\
\text { systems (e.g., } \\
\text { fuel } \\
\text { consumption) }\end{array}$ & & & & & \\
\hline
\end{tabular}

\subsection{Additional Metrics}

In addition to the BWRS, SART, and CLSA data, other metrics are used to evaluate the overall crew workload and SA during missions. These sources include a Pilot-Crewstation Interface (PCI) survey distributed at the end of all missions, subject matter expert (SME) ratings, and pilot interviews. 


\subsubsection{PCI Evaluation}

PCI evaluations are used to examine the interaction between the pilots and the crewstation interface. The PCI impacts crew workload and SA during a mission. A PCI that is designed to augment the cognitive and physical abilities of crews will minimize workload, enhance SA, and contribute to successful mission performance. To assess the PCI, the pilots report any problems that contributed to high workload and low SA at the end of each mission. They also complete a lengthy questionnaire (appendix $\mathrm{C}$ ) at the end of their final mission. The questionnaire addresses usability characteristics of the PCI (e.g., software interface, control reach, and button presses).

\subsubsection{Subject Matter Experts}

SMEs observe the missions and rate pilot workload and SA, mission success, and levels of crew coordination (appendix D) that they observe during the missions. A SME is typically an experienced pilot that has in-depth knowledge of the aircraft and crewstation being assessed. The ratings provided by the SME are compared with the corresponding pilot ratings to identify any significant anomalies in perceived levels of workload or SA while interacting with the crewstation.

\subsubsection{Pilot Interviews}

Pilots are formally interviewed about their performance during after-action reviews in which the mission events and goal outcomes are discussed. Pilots are also interviewed informally by ARL/HRED researchers throughout the test process to gain insights into procedures and to capture any additional comments or perceptions of workload and SA experienced during the missions. Pilots also complete a form providing recommendations for improvements to the crewstation. Recommended design improvements made by the pilots are addressed in future design analyses and incorporated into software and hardware modifications (within funding constraints).

\section{Crewstation Assessment During Simulation and Operational Testing}

\subsection{Crewstation Assessment Methodology}

ARL/HRED developed a methodology to assess crewstation design. The methodology includes: anthropometric modeling; human factors evaluation during simulation and operational testing to assess pilot workload, SA, crew coordination, PCI, and anthropometric accommodation; and use of a head and eye tracker to assess visual gaze and dwell times. This methodology has been used to help develop all modernized U.S. Army Aviation systems including the AH-64D/E Apache, UH-60M Blackhawk, CH-47F Chinook, OH-58F Kiowa, and UH-72A Lakota. The methodology was also used to develop aircraft that are no longer being developed by the Army, including the C-27J Spartan, RAH-66 Comanche, and Armed Reconnaissance Helicopter (ARH). Data 
collected using this methodology are analyzed and used to construct a comprehensive profile of the PCI characteristics and impact on crew workload and SA. Additional information and summary results about each of the steps in the methodology can be found in a report (Hicks and Durbin, 2013) that explains the crewstation assessment process.

\subsection{Simulation and Operational Testing}

The simulators used by ARL/HRED for crewstation design assessments are engineering simulators. The engineering simulators represent the intended production design and provide a platform for developing and assessing crewstation design, evaluating pilot performance, and assessing crew workload, SA, and crew coordination. Pilots with broad levels of experience (e.g., 500-4000 flight hours) typically participate in the simulation events. This wide range of experience provides ARL/HRED researchers a broad perspective on the design of each crewstation. Pilots use the simulators to conduct operationally relevant missions and tasks (e.g., zone reconnaissance, call for fire, troop transport). The simulators are also used to help pilots develop tactics, techniques and procedures and provide limited training for pilots prior to operational testing in the aircraft. Results of the assessments are provided by ARL/HRED to the aircraft program managers, Training and Doctrine Command Capability Managers, Army Test and Evaluation Command, Aviation and Missile Research, Development and Engineering Center, and defense contractors.

Simulators used by ARL/HRED include the OH-58F Kiowa, AH-64D Apache Longbow Risk and Cost Reduction Simulator (RACRS), UH-60M Blackhawk Helicopter Engineering and Analysis Cockpit (BHEAC) - Battlefield Highly Immersive Virtual Environment 1 (BHIVE 1) and Systems Integration Laboratory (SIL) simulators, CH-47F Chinook Helicopter Engineering and Analysis Cockpit (CHEAC) - BHIVE 2 simulator, ARH simulator - BHIVE 2, and the RAH-66 Comanche Engineering Development Simulator (EDS) and Comanche Portable Cockpit (CPC). The simulators contained the hardware and software that emulated the controls, flight characteristics, out-the-window display, and functionality of the aircraft. The simulator crewstations replicated the corresponding crewstation in the actual aircraft, allowing each pilot to perform realistic flight and mission tasks. Table 5 lists the aircraft, associated simulator, and assessment or operational test that was conducted.

Operational tests are conducted to verify design requirements and ensure crewstation designs are ready for fielding. ARL/HRED helps conduct operational tests and typically collects the same data as was collected during the simulations. This provides a progressive assessment of pilot performance and crewstation design. Results from the operational test are compared with the simulations to ensure improvements have been made to the crewstation design and to identify any new human factors design problems. 
Table 5. U.S. Army aircraft, associated simulator, and assessment or test.

\begin{tabular}{|c|c|c|}
\hline Aircraft & Simulator & Assessment/Test \\
\hline AH-64D & RACRS & $\begin{array}{l}\text { Unmanned Aircraft System } \\
\text { (UAS) Teaming for Integrated } \\
\text { and Federated Systems }\end{array}$ \\
\hline AH-64E & - & $\begin{array}{l}\text { Limited User Test (LUT) and } \\
\text { Initial Operational Test (IOT) }\end{array}$ \\
\hline ARH & BHIVE 2 & $\begin{array}{c}\text { Common Aviation Architecture } \\
\text { System (CAAS) Assessment } \\
\text { LUT }\end{array}$ \\
\hline $\mathrm{CH}-47 \mathrm{~F}$ & BHIVE 2 & $\begin{array}{c}\text { CAAS Assessment } \\
\text { Horizontal Situation } \\
\text { Display-Hover (HSDH) } \\
\text { 2-D HUD Improvements } \\
\text { Air Soldier System } \\
\text { 3-D Conformal Symbology }\end{array}$ \\
\hline $\mathrm{C}-27 \mathrm{~J}$ & - & $\begin{array}{c}\text { Multi-Service Operational Test } \\
\text { (MOT) }\end{array}$ \\
\hline $\mathrm{OH}-58 \mathrm{~F}$ & BHIVE 2 & $\begin{array}{c}\text { Human Factors Engineering } \\
\text { (HFE) \#1, 2, } 3 \text { Design } \\
\text { Assessment }\end{array}$ \\
\hline RAH-66 & $\mathrm{CPC}, \mathrm{EDS}$ & $\begin{array}{l}\text { Force Development Test and } \\
\text { Experimentation (FDT\&E) } 1\end{array}$ \\
\hline UH-60L & BHIVE 1, BHEAC, SIL & $\begin{array}{c}\text { Air Soldier System } \\
\text { Multi-Modal Cueing } \\
\text { Pre-MS B } \\
\text { Air Soldier System } \\
\text { 3-D Conformal Symbology }\end{array}$ \\
\hline UH-60M & BHIVE 1, BHEAC, SIL & $\begin{array}{c}\text { Early User Demonstration } \\
\text { (EUD) } \\
\text { Limited Early User } \\
\text { Evaluation (LEUE) } \\
\text { LUT } \\
\text { Required Navigation } \\
\text { Performance/Area Navigation } \\
\text { (RNP/RNAV) EUD } \\
\text { Tactical Airspace Integration } \\
\text { (TAIS) } 1 \& 2 \\
\text { Mission Information } \\
\text { Management (MIM) } 1 \& 2\end{array}$ \\
\hline
\end{tabular}


Examples of simulators that ARL/HRED uses to assess pilot workload and SA include the $\mathrm{OH}-58 \mathrm{~F}$ simulator (figure 3) and the AH-64D Apache simulator (figure 4).
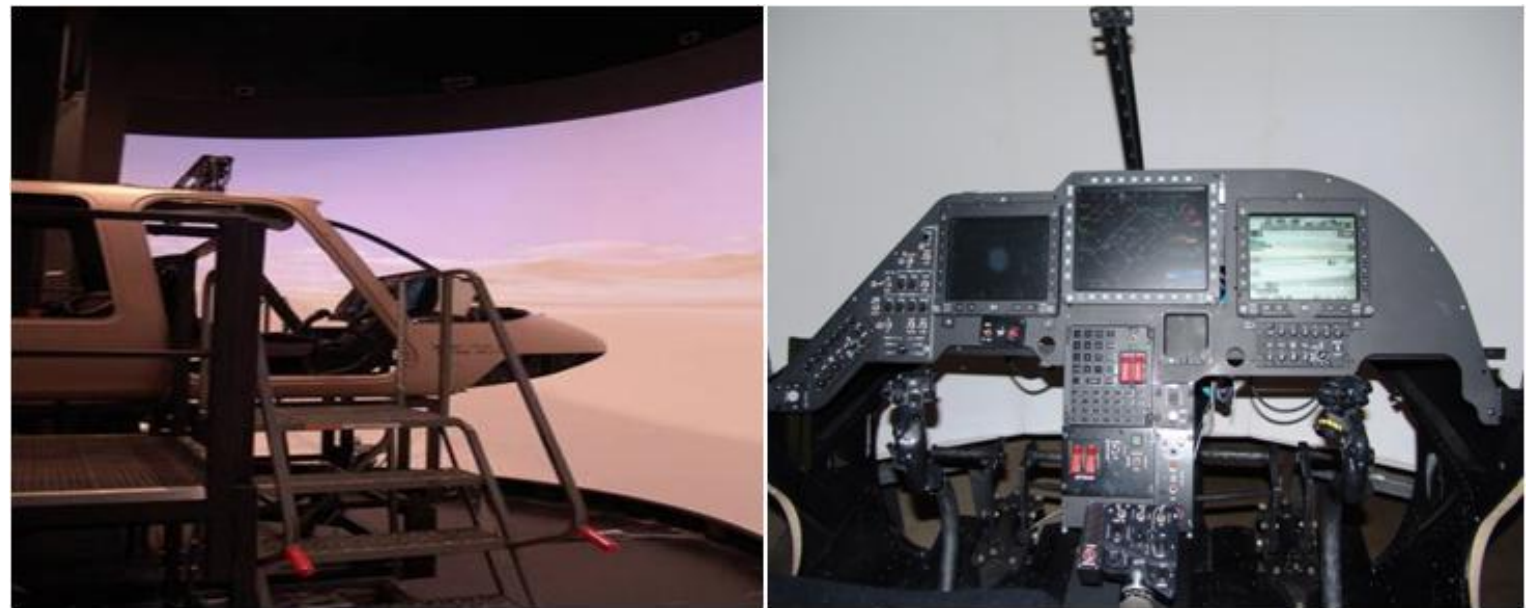

Figure 3. OH-58F crewstation simulator.

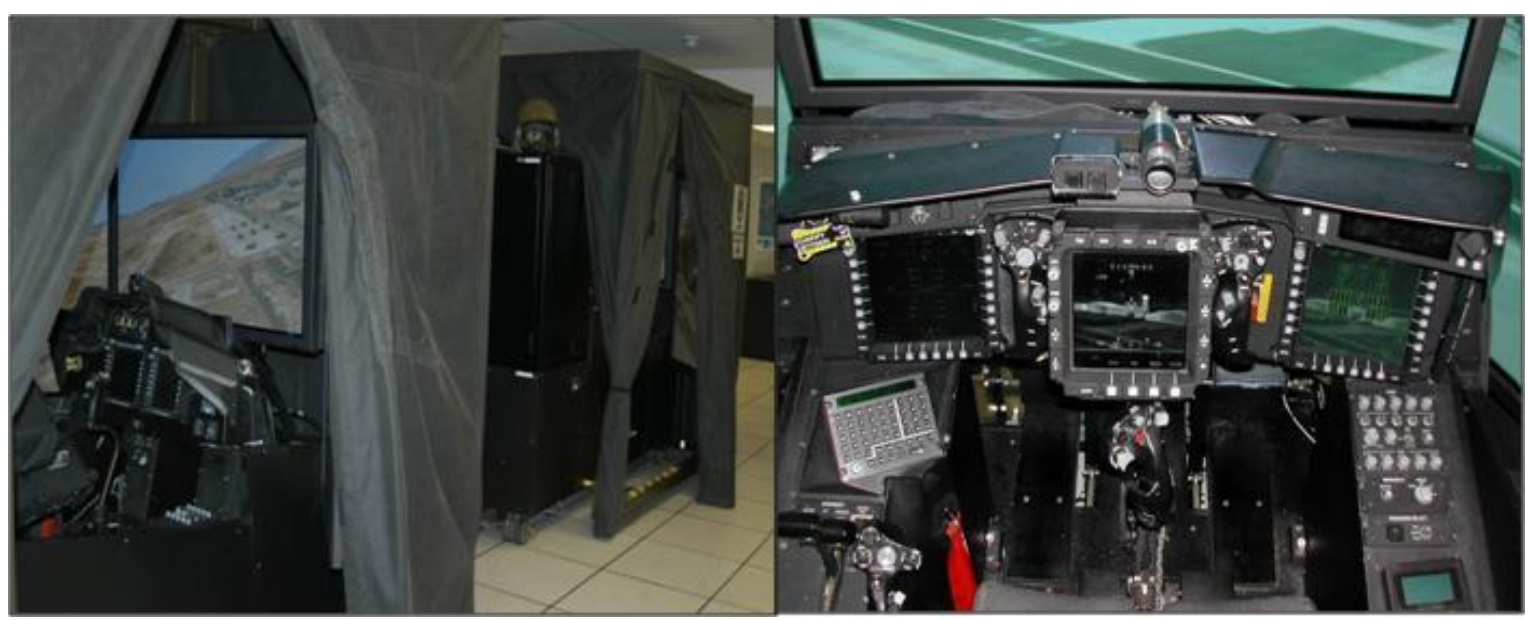

Figure 4. AH-64D Apache Longbow crewstation simulator.

\subsection{Visual Workload}

To help assess pilot workload, SA, and overall crewstation design, pilots wear an eye tracker to record visual gaze and dwell times during missions conducted in the simulators equipped with head trackers. Recording visual gaze and dwell times can identify improvements that need to be made to crewstation design by identifying mission or task segments that require high visual workload. For example, if pilots spend an excessive amount of time viewing the crewstation displays, this can indicate that the displays contain information that requires too many steps (e.g. button pushes, interpretation) to retrieve. Head and eye tracker data are used in combination with BWRS and SA data to help determine high-workload tasks. The inclusion of head and eye tracker data provides objective performance data that can augment the subjective data collected from the crew workload and SA ratings. When pilots spend an excessive amount of time "heads 
down" or inside the cockpit, their workload ratings are often higher. Situational awareness ratings during excessive heads-down time are usually task-dependent. In some cases, higher workload may actually result in higher SA if a pilot is engaging in tasks that would increase SA of a particular event such as locating enemies or identifying terrain features. Figure 5 shows an example of eye tracker data collected from a copilot-gunner during an AH-64D simulation. ARL/HRED compiled a summary of Army Aviation eye tracker data (Hicks et al., 2012) that documented data collection methodology and results.

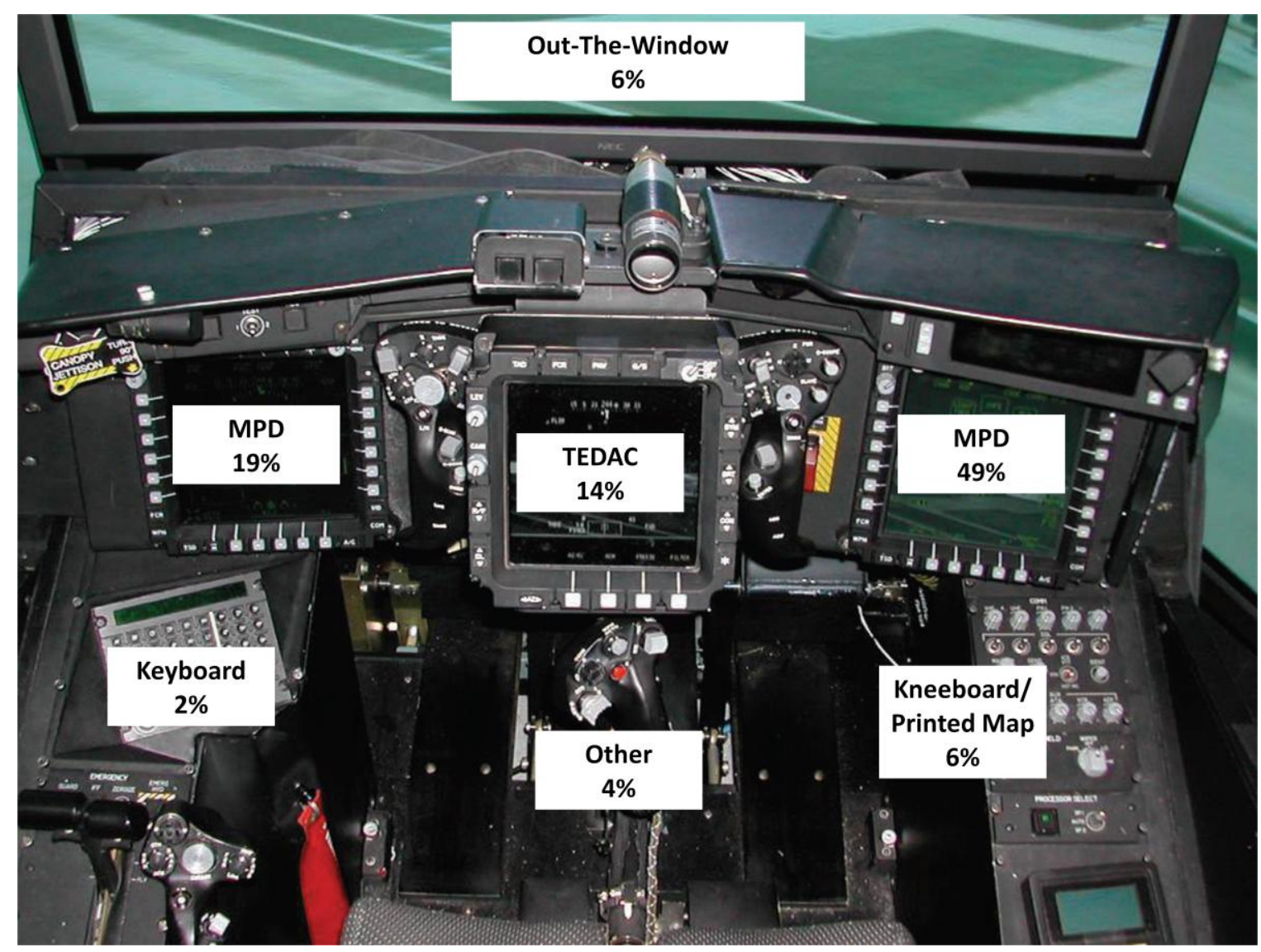

Figure 5. Eye tracker data collected from AH-64D Apache.

\section{Workload and SA Ratings}

\subsection{Bedford Workload Rating Scale Ratings}

The pilots completed the BWRS (appendix A) immediately after each mission to rate the level of workload that they experience when performing flight and mission tasks. The ratings are compared against the workload rating requirements for the aircraft (as applicable) to determine if the crewstation design is imposing excessive workload on the pilots. Table 6 shows a summary of overall workload averages collected during the simulations and operational tests. The ratings 
indicate that the pilots and copilots typically experienced moderate overall workload with either no reduction in spare workload capacity or insufficient to reduced spare workload capacity during the simulations and tests. A rating of 4 or higher on the BWRS indicates that the pilots and copilots had a reduction in spare workload capacity to perform tasks. The one exception was the ARH-70 LUT. Copilots experienced high workload during the LUT because the crewstation display menu structure was nonintuitive and time-consuming to navigate, and the aircraft day TV and Forward-Looking Infrared (FLIR) sensor was difficult to control. In the case of the 3-D conformal tests for $\mathrm{CH}-47 \mathrm{~F}$ and $\mathrm{UH}-60 \mathrm{~L} / \mathrm{M}$, higher workload ratings were due to the crews performing challenging tasks such as takeoffs and landings in brown-out conditions using new symbology designs.

Table 6. Overall workload averages.

\begin{tabular}{|c|c|c|}
\hline \multicolumn{2}{|c|}{ Bedford Workload Ratings - Overall Workload Averages } \\
\hline System/Test & Copilot & Pilot \\
\hline AH-64D - Federated (UAS) & 3.30 & 2.60 \\
\hline AH-64D - Integrated (UAS) & 2.60 & 2.90 \\
\hline AH-64E IOT & 2.50 & 2.50 \\
\hline AH-64E LUT & 4.22 & 3.22 \\
\hline ARH - CAAS & 3.71 & 3.94 \\
\hline ARH LUT & 7.39 & 4.11 \\
\hline CH-47F - CAAS & 2.66 & 2.70 \\
\hline CH-47F - HSDH & 2.41 & 3.36 \\
\hline CH-47F - 2-D HUD & 3.31 & 3.81 \\
\hline CH-47F - 3-D Conformal & 3.70 & 4.10 \\
\hline C-27J MOT & 2.17 & 2.13 \\
\hline OH-58F - HFE \#2 & 3.17 & 3.00 \\
\hline OH-58F - HFE \#3 & 3.44 & 2.56 \\
\hline RAH-66 - FDTE 1 & 3.08 & 2.90 \\
\hline UH-60M - LEUE & 3.33 & 2.98 \\
\hline & & \\
\hline & & \\
\hline & & \\
\hline & & \\
\hline & & \\
\hline & & \\
\hline & & \\
\hline
\end{tabular}


Table 6. Overall workload averages (continued).

\begin{tabular}{|c|c|c|}
\hline \multicolumn{2}{|c|}{ Bedford Workload Ratings - Overall Workload Averages } \\
\hline System/Test & Copilot & Pilot \\
\hline UH-60M - LUT & 2.80 & 2.58 \\
\hline UH-60M - EUD & 2.71 & 2.16 \\
\hline UH-60M - TAIS 1 & 1.87 & 2.42 \\
\hline UH-60M - TAIS 2 & 2.93 & 2.66 \\
\hline UH-60M - MIM 1 & 2.22 & 2.39 \\
\hline UH-60M - MMI 2 & 2.35 & 2.20 \\
\hline UH-60L - Multi-Modal Cues & 2.93 & 3.38 \\
\hline UH-60L - 3-D Conformal & 4.27 & 4.92 \\
\hline
\end{tabular}

\subsection{SART and CLSA Ratings}

The pilots completed the SART or CLSA immediately after each mission to rate the level of SA they experienced while performing the mission. They also rated their level (high-low) of SA of battlefield elements (e.g., location of enemy units). These data provide ARL researchers information on how well the pilots perceived the simulation environment and potential threats. The battlefield elements situation awareness questionnaire is completed in conjunction with the SART or CLSA questionnaire after each mission. Table 7 shows a summary of overall SART and CLSA score averages collected during the simulations and operational tests. The data indicate that the pilots typically experienced moderate to above moderate levels of SA. The one exception was the ARH CAAS. The pilot and copilot SA ratings indicate that they experienced lower levels of SA due to the workload required to navigate the display menu structure and difficulty controlling the aircraft day TV and FLIR. The CLSA data for the UH-60L and CH-47F were obtained using an inverse scale where higher ratings were indicative of better SA as opposed to the traditional CLSA scale. CLSA ratings would have ranged between 1 and 2 for the UH-60L and CH-47F if they had been obtained with the traditional scale. SA ratings for the AH-64E IOT, ARH LUT, and C-27J MOT were not available for inclusion in the table. 
Table 7. Overall SART and CLSA averages.

\begin{tabular}{|c|c|c|}
\hline \multicolumn{2}{|c|}{ Situation Awareness Rating Technique - Overall Averages } \\
\hline System/Test & Copilot & Pilot \\
\hline AH-64D - Federated (UAS) & 19.00 & 21.30 \\
\hline AH-64D - Integrated (UAS) & 18.40 & 23.20 \\
\hline ARH - CAAS & 17.67 & 17.22 \\
\hline CH-47F - CAAS & 23.83 & 20.13 \\
\hline RAH-66 - FDTE 1 & 21.86 & 22.40 \\
\hline UH-60M - LEUE & 26.42 & 25.25 \\
\hline UH-60M - LUT & 28.28 & 28.22 \\
\hline UH-60M - TAIS 1 & 33.78 & 18.66 \\
\hline UH-60M - TAIS 2 & 17.66 & 20.60 \\
\hline UH-60L - Multi-Modal Cues & 29.33 & 19.95 \\
\hline China Lake Situational Awareness Scale - Overall Averages \\
\hline System/Test & Co-Pilot & Pilot \\
\hline AH-64E LUT & 1.94 & 1.74 \\
\hline OH-58F - HFE \#2 & 2.75 & 2.50 \\
\hline OH-58F - HFE \#3 & 2.22 & 1.67 \\
\hline UH-60L - Multi-Modal Cues & 3.94 & 3.75 \\
\hline UH-60L - 3-D Conformal & 3.74 & 3.67 \\
\hline CH-47F - 3-D Conformal & & \\
\hline
\end{tabular}

\section{Summary}

The method that ARL/HRED uses to assess the human factors characteristics of U.S. Army Aviation helicopter crewstations has been successful in evaluating crew workload and SA, and eliminating human factors design problems. To date, more than 500 crewstation design improvements have been made to resolve the human factors problems and enhance crew performance. Examples include software improvements to crewstation displays such as enhanced functionality and presentation of display pages to pilots, improved color-coding of battlefield graphics, reduced number of button presses to display information, enhanced readability of 
display map pages, and improved presentation of aircraft operational limits. Hardware improvements include: modifications to crewstation seats, consoles, and glare shields to improve visual access and physical reach to displays and controls; improved functionality of flight helmets and helmet-mounted displays; and optimized crewstation switch location and function. These improvements are documented in ARL technical reports and Army Aviation programmatic and technical documents.

The benefits to using the crewstation assessment method to assess crew workload, SA, and crewstation design are (1) iterative crewstation evaluations drive continuous incremental improvements, (2) improvements are identified in near real time, which aids rapid modification, (3) identifies crewstation design that needs further improvement, (4) issues documented for one aircraft often apply to new or updated aircraft, which helps with early identification of issues for these aircraft, and (5) results feed the assessments used by acquisition officials to determine whether to manufacture and field Army Aviation aircraft.

ARL/HRED will continue to assess crew workload and SA and thereby improve crewstation design to meet the demands of the next generation of Army aircraft. 


\section{References}

Eisen, P. S.; Hendy, K. C. A Preliminary Examination of Mental Workload: Its Measurement and Prediction. Defence and Civil Institute of Environmental Medicine 1987, 87 (57), 1-84.

Endsley, M. R. Design and Evaluation for Situation Awareness Enhancement. Proceedings of the Human Factors Society 32nd Annual Meeting; Anaheim, CA, 24-28 October 1988; Vol. 1, pp 92-101.

Endsley, M. R. Toward a Theory of Situation Awareness in Dynamic Systems: Human Factors 1995, 37 (1), 32-64.

Endsley, M. R. Situation Awareness Analysis and Measurement; Lawrence Erlbaum Associates: Mahwah, NJ, 2000.

Hicks, J.; Durbin, D. B. A Method to Assess the Human Factors Characteristics of Army Aviation Helicopter Crewstations; ARL-TR-6388; U.S. Army Research Laboratory: Aberdeen Proving Ground, MD, March 2013.

Hicks, J. S.; Jessee, M. S.; Durbin, D. B. A Summary of Visual Gaze and Dwell Times for Army Pilots During Mission Simulations; ARL-TR-5900; U.S. Army Research Laboratory:

Aberdeen Proving Ground, MD, 2012.

Roscoe, A. H. The Airline Pilot's View of Flight Deck Workload: A Preliminary Study Using a Questionnaire; Technical Memorandum No. FS (B) 465; Royal Aircraft Establishment: Bedford, UK, 1985; ADA116314.

Roscoe, A. H.; Ellis, G. A. A Subjective Rating Scale for Assessing Pilot Workload in Flight: A Decade of Practical Use; Royal Aerospace Establishment: Bedford, UK, 1990.

Salmon, P.; Walker, G.; Green, D. Situation Awareness Measurement: A Review of Applicability for C4i Environments. Applied Ergonomics 2006, 38 (1), 119.

Taylor, R. M. Situational Awareness Rating Technique (SART): The Development of a Tool for Aircrew Systems Design. Proceedings of the NATO Advisory Group on Aerospace Research and Development (AGARD) Symposium on Situational Awareness in Aerospace Operations; AGARD-CP-478, 3/1-3/17; NATO - AGARD: Neuilly Sur Seine, France, 1989. 
Appendix A. Bedford Workload Rating Scale and Questionnaire

The appendix appears in its original form, without editorial change. 


\section{Workload}

Rate the workload for the Flight and Mission Tasks you performed (on the 2nd page) using the workload scale below. Place the workload rating in the blank next to each Flight and Mission Task.

Workload Description

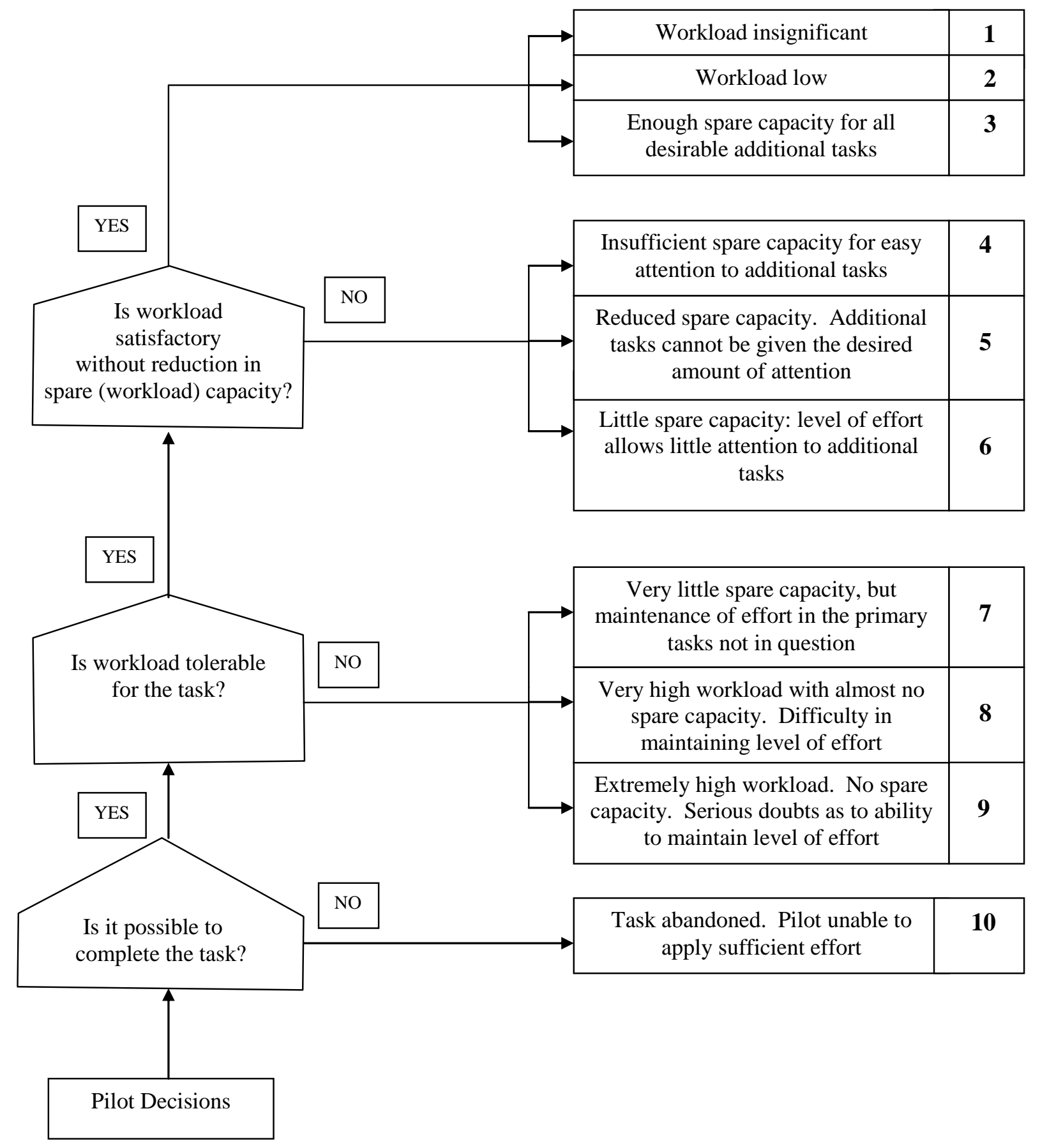




\section{Pilot Workload}

Rate the workload for the Flight and Mission Tasks you performed during the mission that you just completed. Use the scale provided on the last page of this questionnaire. Place the workload rating in the blank next to each Flight and Mission Task. If you did not perform a task during the mission that you just completed, place an $\mathrm{X}$ in the non-applicable (NA) column.

\begin{tabular}{|c|c|c|c|}
\hline $\begin{array}{l}\text { Task } \\
\text { No. }\end{array}$ & Flight and Mission Tasks & Workload Rating & NA \\
\hline 1026 & Maintain Airspace Surveillance & & \\
\hline 1028 & Perform Hover Power Check & & \\
\hline 1030 & Perform Hover Out-Of-Ground-Effect (OGE) Check & & \\
\hline 1032 & Perform Radio Communication Procedures & & \\
\hline 1038 & Perform Hovering Flight & & \\
\hline 1040 & Perform Visual Meteorological Conditions (VMC) Takeoff & & \\
\hline 1044 & Navigate by Pilotage and Dead Reckoning & & \\
\hline 1046 & Perform Electronically Aided Navigation & & \\
\hline 1048 & Perform Fuel Management Procedures & & \\
\hline 1052 & Perform VMC Flight Maneuvers & & \\
\hline 1058 & Perform VMC Approach & & \\
\hline---- & Level of Interoperability (LOI) 2 with UAS & & \\
\hline 1066 & Perform A Running Landing & & \\
\hline 1070 & Respond to Emergencies & & \\
\hline 1074 & Respond to Engine Failure in Cruise Flight & & \\
\hline 1140 & Perform Nose Mounted Sensor (NMS) Operations & & \\
\hline 1142 & Perform Digital Communications & & \\
\hline 1155 & Negotiate Wire Obstacles & & \\
\hline 1170 & Perform Instrument Takeoff & & \\
\hline 1176 & Perform Non Precision Approach (GCA) & & \\
\hline 1178 & Perform Precision Approach (GCA) & & \\
\hline 1180 & Perform Emergency GPS Recovery Procedure & & \\
\hline 1082 & Perform an Autorotation & & \\
\hline 1182 & Perform Unusual Attitude Recovery & & \\
\hline 1188 & Operate ASE/transponder & & \\
\hline 1184 & Respond to IMC Conditions & & \\
\hline 1194 & Perform Refueling /Rearming Operations & & \\
\hline 1404 & $\begin{array}{l}\text { Perform Electronic Countermeasures ElectroniclCounter- } \\
\text { Countermeasures }\end{array}$ & & \\
\hline 1405 & Transmit Tactical Reports & & \\
\hline 1407 & Perform Terrain Flight Takeoff & & \\
\hline 1408 & Perform Terrain Flight & & \\
\hline 1409 & Perform Terrain Flight Approach & & \\
\hline 1410 & Perform Masking and Unmasking & & \\
\hline 1411 & Perform Terrain Flight Deceleration & & \\
\hline
\end{tabular}




\begin{tabular}{|c|c|c|c|}
\hline $\begin{array}{c}\text { Task } \\
\text { No. }\end{array}$ & Flight and Mission Tasks & Workload Rating & NA \\
\hline 1413 & Perform Actions on Contact & & \\
\hline 1416 & Perform Weapons Initialization Procedures & & \\
\hline 1422 & Perform Firing Techniques & & \\
\hline 1456 & Engage Target with .50 Cal & & \\
\hline 1458 & Engage Target with Hellfire & & \\
\hline 1462 & Engage Target with Rockets & & \\
\hline 1472 & Perform Aerial Observation & & \\
\hline 1471 & Perform Target Handover & & \\
\hline 1472 & Aerial Observation & & \\
\hline 1473 & Call for Indirect Fire & & \\
\hline 2010 & Perform Multi-Aircraft Operations & & \\
\hline 2127 & Perform Combat Maneuvering Flight & & \\
\hline 2128 & Perform Close Combat Attack & & \\
\hline 2129 & Perform Combat Position Operations & & \\
\hline 2164 & Call for Tactical Air Strike & & \\
\hline---- & Zone Reconnaissance & & \\
\hline---- & Route Reconnaissance & & \\
\hline---- & Area Reconnaissance & & \\
\hline---- & Aerial Surveillance & & \\
\hline---- & Overall Workload for the Mission & & \\
\hline
\end{tabular}

If you gave a workload rating of ' 5 ' or higher for any task, explain why the workload was high for the task. 


\section{Appendix B. SART and CLSA Rating Scales}

The appendix appears in its original form, without editorial change. 
Situation Awareness is defined as "timely knowledge of what is happening as you perform your right or left seat tasks during the mission."

\begin{tabular}{|l|l|}
\hline \multicolumn{2}{|c|}{ Situation Awareness Rating Technique (SART) } \\
\hline \multicolumn{2}{|c|}{ DEMAND } \\
\hline Instability of Situation & Likeliness of situation to change suddenly \\
\hline Variability of Situation & Number of variables which require your attention \\
\hline Complexity of Situation & Degree of complication (number of closely connected parts) of the situation \\
\hline \multicolumn{2}{|c|}{ SUPLY } \\
\hline Arousal & Degree to which you are ready for activity \\
\hline Spare Mental Capacity & Amount of mental ability available to apply to new tasks \\
\hline Concentration & Degree to which your thoughts are brought to bear on the situation \\
\hline Division of Attention & Amount of division of your attention in the situation \\
\hline \multicolumn{2}{|c|}{ UNDERSTANDING } \\
\hline Information Quantity & Amount of knowledge received and understood \\
\hline Information Quality & Degree of goodness or value of knowledge communicated \\
\hline Familiarity & Degree of acquaintance with the situation \\
\hline
\end{tabular}


Rate the level of each component of situation awareness that you had when you performed 'flying pilot' tasks in the right seat -or- 'non-flying' pilot tasks in the left seat during the mission that you just completed. Circle the appropriate number for each component of situation awareness (e.g., complexity of situation).

\section{DEMAND}

Instability of situation: Low 1---------2---------3---------4---------5---------6---------7 High

Variability of situation: Low 1---------2---------3----------4---------5----------6---------7 High

Complexity of situation: Low 1---------2---------3---------4---------5---------6---------7 High

\section{SUPPLY}

Arousal: $\quad$ Low 1---------2---------3---------4---------5---------6---------7 High

Spare mental capacity: Low 1---------2----------3---------4---------5---------6----------7 High

Concentration: $\quad$ Low 1---------2---------3---------4---------5---------6---------7 High

Division of attention: Low 1---------2---------3---------4---------5---------6---------7 High

\section{UNDERSTANDING}

\begin{tabular}{|c|c|c|}
\hline Information quantity: & Low & 1---------2----------3----------4----------5----------6---------' \\
\hline Information quality: & Low & 1---------2----------3---------4---------5---------6---------7 \\
\hline Familiarity: & Low & 1---------2---------3---------4---------5---------6---------7 \\
\hline
\end{tabular}

\section{Battlefield Elements}

Rate the level of situation awareness you had for each battlefield element during the mission? (Place an $\mathrm{X}$ in the appropriate column for each battlefield element). 


\begin{tabular}{|c|c|c|c|c|c|}
\hline $\begin{array}{c}\text { Battlefield } \\
\text { Elements }\end{array}$ & $\begin{array}{c}\text { Very High } \\
\text { Level of } \\
\text { Situation } \\
\text { Awareness }\end{array}$ & $\begin{array}{c}\text { Fairly High } \\
\text { Level of } \\
\text { Situation } \\
\text { Awareness } \\
\end{array}$ & Borderline & $\begin{array}{c}\text { Fairly Low } \\
\text { Level of } \\
\text { Situation } \\
\text { Awareness } \\
\end{array}$ & $\begin{array}{c}\text { Very Low } \\
\text { Level of } \\
\text { Situation } \\
\text { Awareness }\end{array}$ \\
\hline $\begin{array}{l}\text { Location of } \\
\text { Enemy Units }\end{array}$ & & & & & \\
\hline $\begin{array}{l}\text { Location of } \\
\text { Friendly Units }\end{array}$ & & & & & \\
\hline $\begin{array}{l}\text { Location of } \\
\text { Non- } \\
\text { Combatants } \\
\text { (e.g., Civilians) }\end{array}$ & & & & & \\
\hline $\begin{array}{c}\text { Location of My } \\
\text { Aircraft During } \\
\text { Missions }\end{array}$ & & & & & \\
\hline $\begin{array}{l}\text { Location of } \\
\text { Other Aircraft } \\
\text { In My Flight }\end{array}$ & & & & & \\
\hline $\begin{array}{c}\text { Location of } \\
\text { Cultural } \\
\text { Features (e.g., } \\
\text { bridges) }\end{array}$ & & & & & \\
\hline $\begin{array}{c}\text { Route } \\
\text { Information } \\
\text { (ACPs, BPs, } \\
\text { EAs, RPs, etc.) }\end{array}$ & & & & & \\
\hline $\begin{array}{c}\text { Status of My } \\
\text { Aircraft Systems } \\
\text { (e.g., fuel } \\
\text { consumption) }\end{array}$ & & & & & \\
\hline
\end{tabular}

Describe any instances when you had low situation awareness during the mission:

China Lake Situational Awareness Scale 


\begin{tabular}{|c|c|}
\hline CLSA SCALE VALUE & CONTENT \\
\hline Very Good - 1 & $\begin{array}{l}\text { - Full knowledge of } \mathrm{A} / \mathrm{C} \text { energy state/tactical environment/mission. } \\
\text { - Full ability to anticipate/accommodate trends. }\end{array}$ \\
\hline Good -2 & $\begin{array}{l}\text { - Full knowledge of A/C energy state/tactical environment/mission. } \\
\text { - Partial ability to anticipate/accommodate trends; } \\
\text { - No task shedding }\end{array}$ \\
\hline Adequate -3 & $\begin{array}{l}\text { - Full knowledge of A/C energy state/tactical environment/mission. } \\
\text { - Saturated ability to anticipate/accommodate trends; } \\
\text { - Some shedding of minor tasks }\end{array}$ \\
\hline Poor -4 & $\begin{array}{l}\text { - } \text { Fair knowledge of A/C energy state/tactical environment/mission. } \\
\text { - Saturated ability to anticipate/accommodate trends; } \\
\text { - Shedding of all minor tasks as well as many not essential to flight } \\
\text { safety/mission effectiveness }\end{array}$ \\
\hline Very Poor -5 & $\begin{array}{l}\text { - Minimal knowledge of A/C energy state/tactical environment/mission. } \\
\text { - Oversaturated ability to anticipate/accommodate trends; } \\
\text { - Shedding of all tasks not essential to flight safety/mission effectiveness }\end{array}$ \\
\hline
\end{tabular}


INTENTIONALLY LEFT BLANK. 


\section{Appendix C. PCI Questionnaire Example}

The appendix appears in its original form, without editorial change. 
PV1. The following table lists the components of a CAAS crewstation. For each component, indicate whether or not you experienced a problem using the component in a quick and efficient manner during the mission you just completed. Check 'Yes' if you experienced one or more problems. Check 'No' if you did not experience any problems. Check 'Not Used' if you did not use the component during the mission you just completed.

- Multifunction Displays (MFD)

○ Vertical Situation Display (VSD)

- VSD Hover (VSDH)

○ Horizontal Situation Display (HSD)

○ HSD Hover (HSDH)

○ EOS

○ Digital Map Display (DMS)

○ Warning, Caution, Advisory

Display (WCA)

\begin{tabular}{|c|c|c|}
\hline Yes & No & Not Used \\
\hline Yes & No & Not Used_ \\
\hline Yes _ & No _ & Not Used_ \\
\hline Yes & No & Not Used \\
\hline Yes & No & Not Used \\
\hline Yes & No & Not Used_ \\
\hline Yes & No & Not Used \\
\hline
\end{tabular}

- Control Display Unit (CDU)

○ Initializing CDU

- Managing GPS / Flight Plan

- Managing COM, NAV, IFF (CNI)
Yes

Yes

Yes

\section{.}

- Engine Instrument Caution Advisory System (EICAS)

If you answered "Yes" to any of the questions, describe a) the problems you experienced, b) how much the problems degraded your performance, and c) any recommendation you have for improving the design of the various functional components.

PV3. Please answer the following questions regarding the Multifunction Control Unit (MFCU):

PV3-1. Did the functionality of the directional control and switches on the MFCU perform the actions you expected? 


$$
\text { Yes _ No _ Not Used }
$$

PV3-2. Was the sensitivity of the directional control appropriate?

$$
\text { Yes _ No N N Not Used }
$$

PV3-3. Did you experience abnormal hand discomfort while using the MFCU?

$$
\text { Yes __ No _ _ Not Used }
$$

PV3-4. Did you have adequate space in the cockpit to use the MFCU?

$$
\text { Yes _ No _ N Not Used }
$$

If you experienced any problems with the MFCU, please describe the problems in as much detail as you can and make recommendations to correct the problems.

PV4. Did you have difficulty using any of the switches on the collective or cyclic grips?

$\begin{array}{lll}\text { Collective Grip } & \text { Yes } & \text { No } \\ \text { Cyclic Grip } & \text { Yes } & \text { No }\end{array}$

If you answered "Yes" for either flight control, please list which flight control and switch(es), and the problems you experienced (e.g., confused two switches due to similar shape, switch too hard to reach).

PV5. Was there any symbology depicted on the following displays/pages that was difficult to quickly and easily understand, cluttered, or otherwise difficult to use?

Vertical Situation Display (VSD)

VSD Hover (VSDH)

Horizontal Situation Display (HSD)

HSD Hover (HSDH)

EICAS

Digital Map System (DMS)
Yes

Yes

Yes

Yes

Yes

Yes
No

No

No

No

No

No 
If you answered "Yes" to any of the questions, please describe a) the display/page, b) the symbology that was difficult to understand, c) how the symbology may have degraded your performance, and d) any recommendations you have for improving the design of the various functional components.

PV6. How would you rate your ability to detect the following occurrences based on the characteristics of the flight displays?

Caution/Advisory (MFD)

$\begin{array}{lllll}1 & 2 & 3 & 4 & 5\end{array}$

\begin{tabular}{lcccc}
\hline Very & Somewhat & Borderline & Somewhat & Very \\
Easy & Easy & & Difficult & Difficult \\
\multicolumn{2}{l}{ Warning } & (Master Warning Panel) & & \\
1 & 2 & 3 & 4 & 5 \\
\hline Very & Somewhat & Borderline & Somewhat & Very \\
Easy & Easy & & Difficult & Difficult
\end{tabular}

Entry Into Operational Limits

\begin{tabular}{lccrl}
1 & 2 & 3 & 4 & 5 \\
\hline Very & Somewhat & Borderline & Somewhat & Very \\
Easy & Easy & & Difficult & Difficult
\end{tabular}

Low Fuel (MFD)

\begin{tabular}{lccrl}
1 & 2 & 3 & 4 & 5 \\
\hline Very & Somewhat & Borderline & Somewhat & Very \\
Easy & Easy & & Difficult & Difficult
\end{tabular}


If you answered "Somewhat Difficult", or "Very Difficult", please indicate which annunciation you had difficulty detecting, why you may have had difficulty detecting it, and any recommendations to make the annunciation more easily detectable.

PV7. Based on the missions you've conducted this week, what are the top enhancements that should be made to the crewstation to improve pilot performance? 
INTENTIONALLY LEFT BLANK. 


\section{Appendix D. SME Questionnaire}

The appendix appears in its original form, without editorial change. 


\section{Workload}

TSCWL1. Using the workload scale below, rate the overall workload for the crewmembers that you observed (during this mission) on the following page.

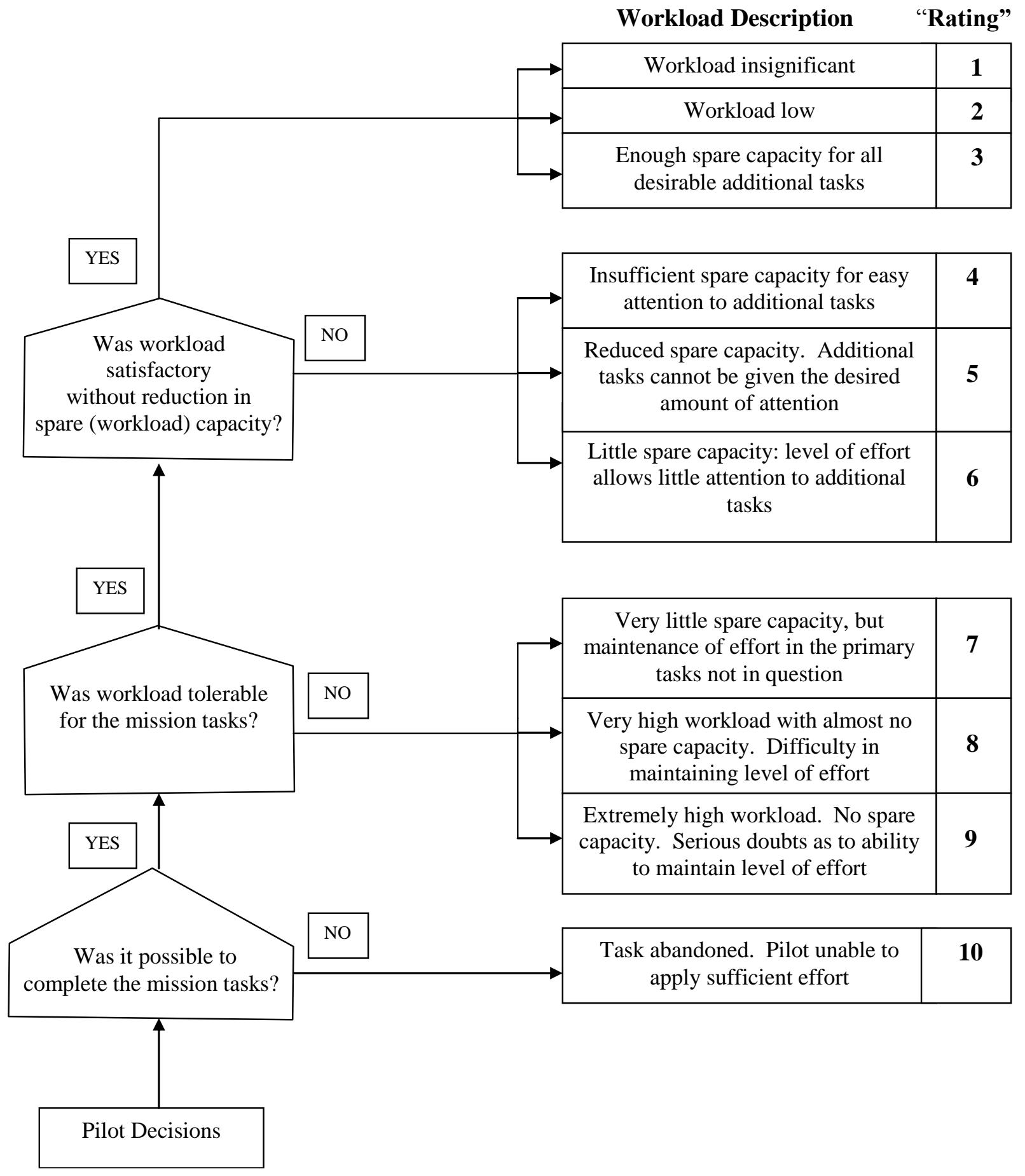


TSCWL1. Place the workload rating in the blank next to each crewmember using the rating scale on the previous page (continued).

\begin{tabular}{|c|c|}
\hline Crewmembers & $\begin{array}{c}\text { Overall Workload Rating For This } \\
\text { Mission }\end{array}$ \\
\hline Left Seat & \\
\hline Right Seat & \\
\hline
\end{tabular}

If you assigned a workload rating of ' 6 ' or higher for either crewmember, explain why:

TSCWL2. Which crewmember was the 'flying pilot' for most of the mission?

$$
\text { Left seat _ Right seat }
$$

TSCWL3. What percentage of the time was the crewmember (left seat or right seat in question above) the 'flying pilot' during the mission?

$$
\%
$$

TSCWL4. Rate the effectiveness of aircrew coordination as defined by the USAAVNC Aircrew Coordination ETP and TC 1-210.

1

2
4

Excellent Good Average Needs Improvement Unacceptable 


\section{$\underline{\text { Situation Awareness }}$}

\begin{tabular}{|c|c|}
\hline Rating & Check One \\
\hline Crew was consistently aware of all entities on the battlefield & \\
\hline $\begin{array}{c}\text { Crew was aware of the battlefield with minor or insignificant variation between perception and } \\
\text { reality. }\end{array}$ & \\
\hline $\begin{array}{c}\text { Crew was aware of the battlefield. Variation between reality and perception did not } \\
\text { significantly impact mission success. }\end{array}$ & \\
\hline SA needs improvement. Lack of SA had some negative effect on the success of the mission. & \\
\hline Lack of SA caused mission failure. & \\
\hline
\end{tabular}

Describe any problems that aircrews had with situation awareness. 


\section{List of Symbols, Abbreviations, and Acronyms}

$\begin{array}{ll}\text { ARH } & \text { Armed Reconnaissance Helicopter } \\ \text { ARL } & \text { U.S. Army Research Laboratory } \\ \text { BHEAC } & \text { Blackhawk Helicopter Engineering and Analysis Cockpit } \\ \text { BHIVE } & \text { Battlefield Highly Immersive Virtual Environment } \\ \text { BWRS } & \text { Bedford Workload Rating Scale } \\ \text { CAAS } & \text { Common Aviation Architecture System } \\ \text { CHEAC } & \text { Cargo Helicopter - Engineering Analysis Cockpit } \\ \text { CPC } & \text { Comanche Portable Cockpit } \\ \text { EDS } & \text { Engineering Development Simulator } \\ \text { EUD } & \text { Early User Demonstration } \\ \text { FDT\&E } & \text { Force Development Test and Evaluation } \\ \text { FLIR } & \text { Forward-Looking Infrared } \\ \text { HFE } & \text { Human Factors Engineering } \\ \text { HRED } & \text { Human Research and Engineering Directorate } \\ \text { IOT } & \text { Initial Operational Test } \\ \text { LEUE } & \text { Limited Early User Evaluation } \\ \text { LUT } & \text { Limited User Test } \\ \text { MIM } & \text { Mission Information Management } \\ \text { MOT } & \text { Multi-Service Operational Test } \\ \text { PCI } & \text { Pilot-Crewstation Interface } \\ \text { RACRS } & \text { Risk and Cost Reduction System } \\ \text { RNAV } & \text { Area Navigation } \\ \text { RNP } & \text { Required Navigation Performance } \\ \text { SA } & \text { situation awareness } \\ \text { SART } & \text { Situation Awareness Rating Technique } \\ \text { SIL } & \text { System Integration Laboratory } \\ & \end{array}$


SME subject matter expert

TAIS Tactical Airspace Integration System

UAS Unmanned Aircraft System 


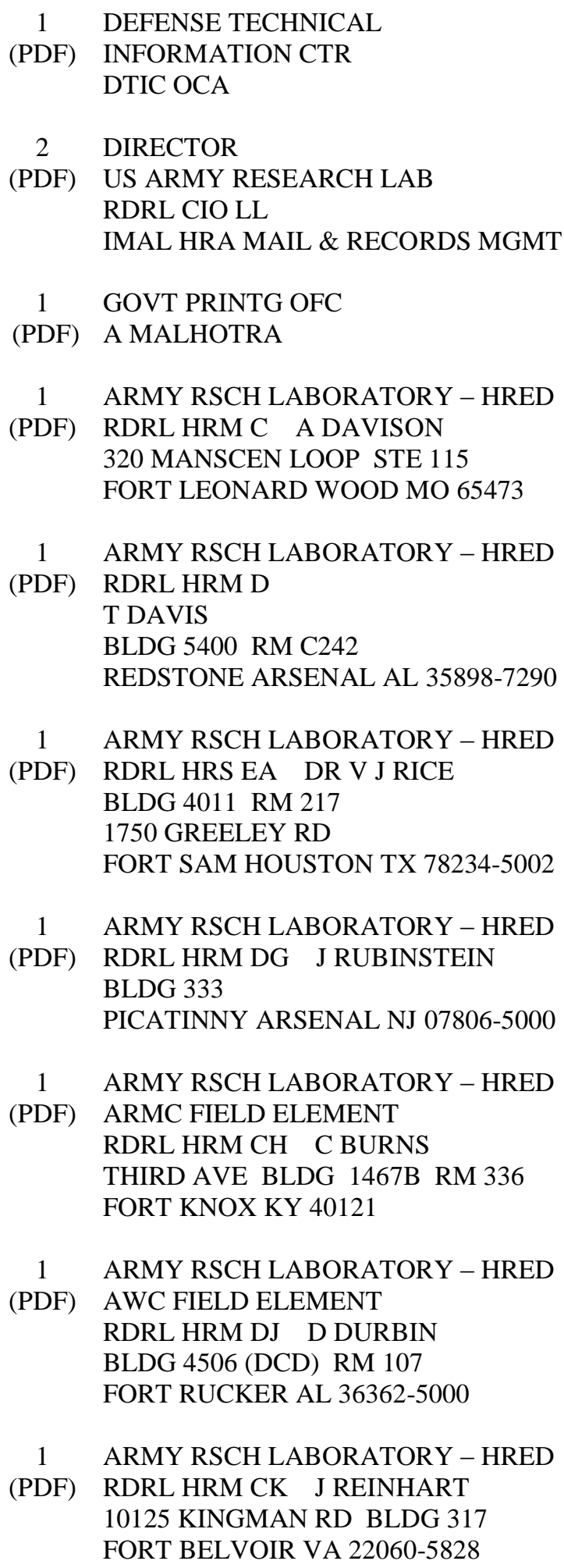

1 ARMY RSCH LABORATORY - HRED

(PDF) RDRL HRM AY M BARNES

2520 HEALY AVE

STE 1172 BLDG 51005

FORT HUACHUCA AZ 85613-7069

1 ARMY RSCH LABORATORY - HRED

(PDF) RDRL HRM AP D UNGVARSKY

POPE HALL BLDG 470

BCBL 806 HARRISON DR

FORT LEAVENWORTH KS 66027-2302
1 ARMY RSCH LABORATORY - HRED
(PDF) RDRL HRM AT J CHEN 12423 RESEARCH PKWY ORLANDO FL 32826-3276
1 ARMY RSCH LABORATORY - HRED
(PDF) RDRL HRM AT C KORTENHAUS 12350 RESEARCH PKWY ORLANDO FL 32826-3276
1 ARMY RSCH LABORATORY - HRED (PDF) RDRL HRM CU B LUTAS-SPENCER 6501 E 11 MILE RD MS 284 BLDG 200A 2ND FL RM 2104 WARREN MI 48397-5000

1 ARMY RSCH LABORATORY - HRED (PDF) FIRES CTR OF EXCELLENCE FIELD ELEMENT RDRL HRM AF C HERNANDEZ 3040 NW AUSTIN RD RM 221 FORT SILL OK 73503-9043

1 ARMY RSCH LABORATORY - HRED (PDF) RDRL HRM AV W CULBERTSON 91012 STATION AVE FORT HOOD TX 76544-5073

1 ARMY RSCH LABORATORY - HRED

(PDF) HUMAN RSRCH AND ENGRNG DIRCTRT MCOE FIELD ELEMENT RDRL HRM DW C CARSTENS 6450 WAY ST BLDG 2839 RM 310 FORT BENNING GA 31905-5400

1 ARMY RSCH LABORATORY - HRED (PDF) RDRL HRM DE A MARES 1733 PLEASONTON RD BOX 3 FORT BLISS TX 79916-6816 


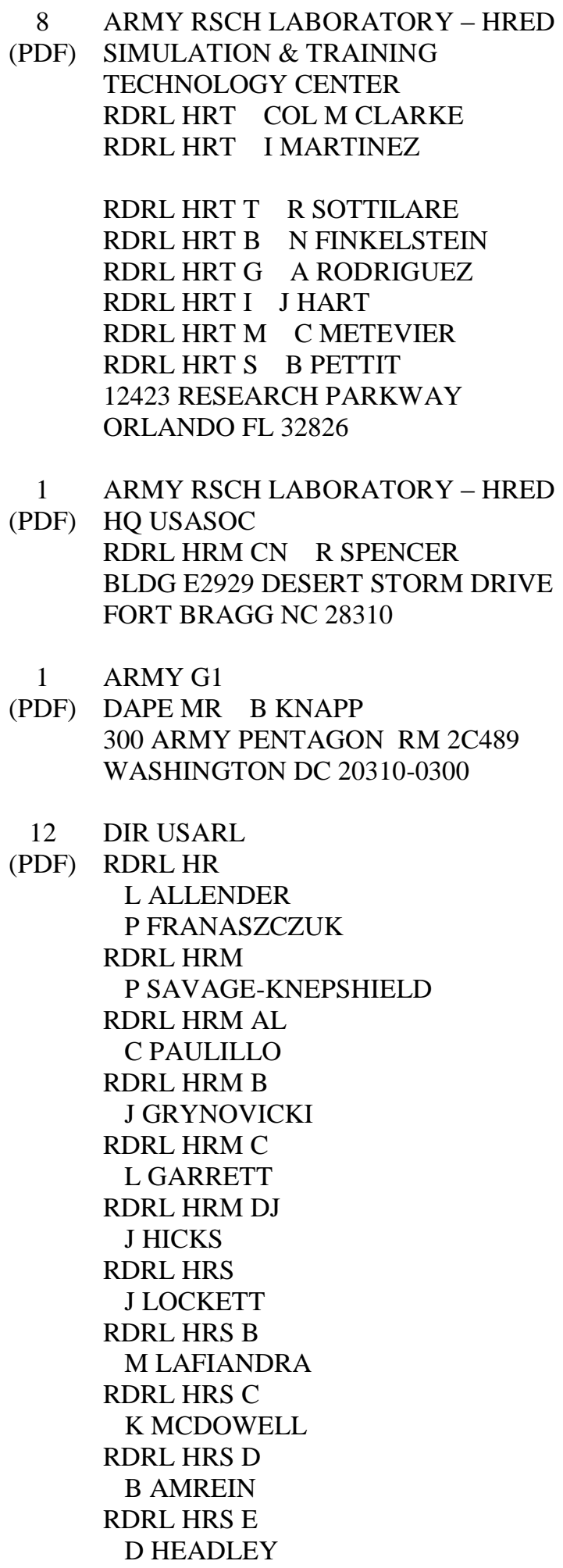

